ANGELA M. VIANNA-MORGANTE CARLA ROSENBERG

As variações do genoma e a diversidade humana 


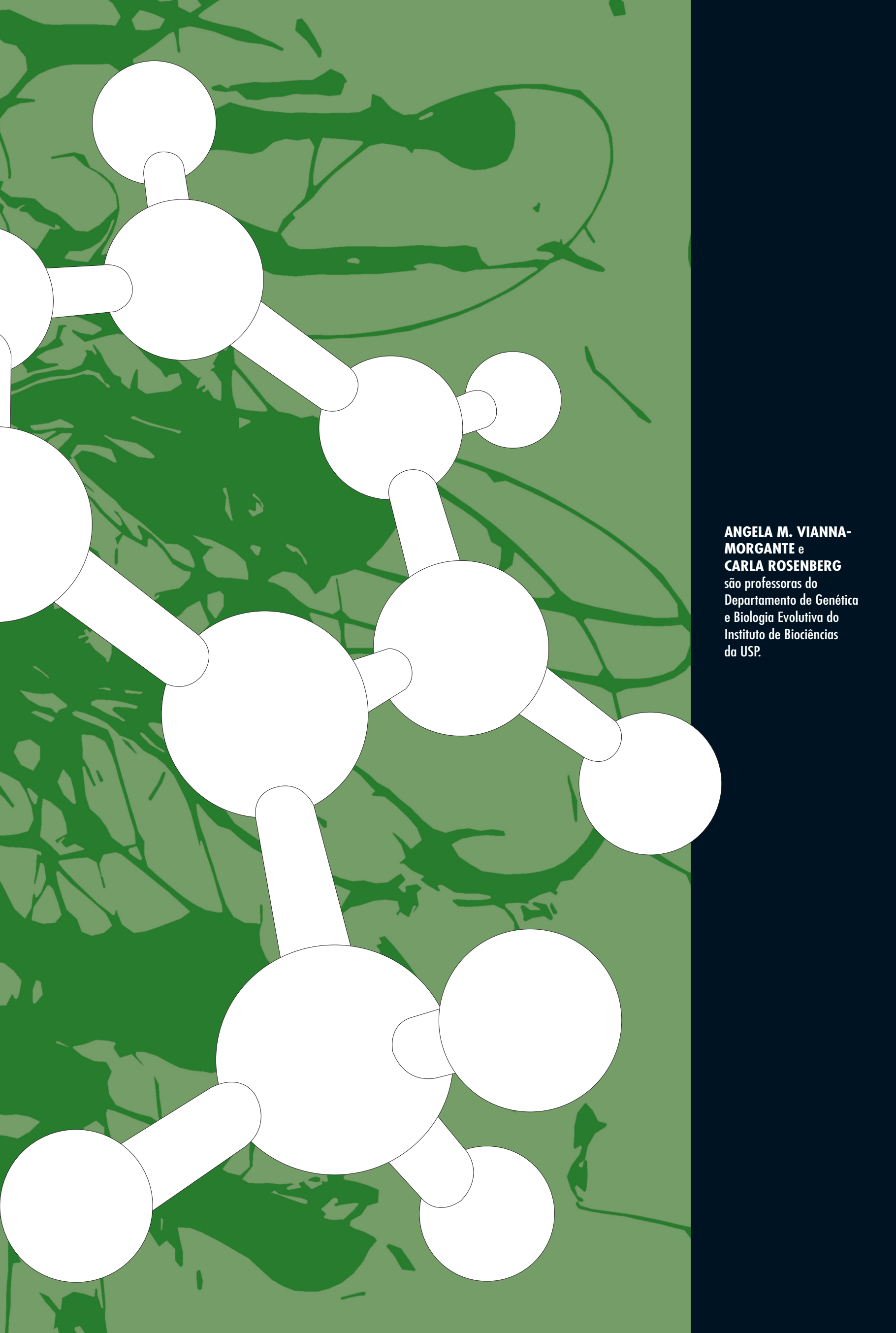




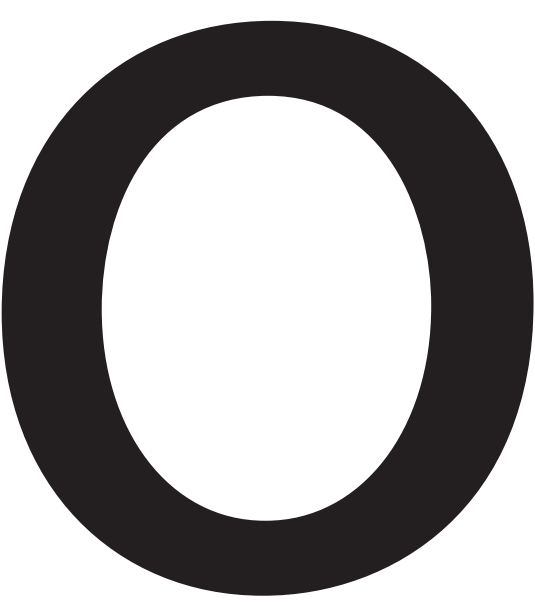

genoma humano está seqüenciado, o que significa que cerca de três bilhões de pares de bases nitrogenadas de nosso DNA foram identificados e têm sua ordem conhecida ${ }^{1}$. Essa seqüência, entretanto, não é exatamente a mesma em todos os indivíduos. Isso fica evidente quando se atenta para a grande diversidade de nossas características. Somos diferentes, por exemplo, quanto à cor da pele, dos cabelos e dos olhos e aos grupos sanguiíneos; as diferenças entre nossas impressões digitais permitem que sejamos identificados. Somos, cada um de nós, geneticamente únicos.
As diferenças entre nossos genomas podem estar no nível dos pares de bases nitrogenadas. Por exemplo, diferentes bases podem ocupar determinados locais na molécula do DNA (Figura 1). Milhões de variações desse tipo já foram identificadas em nosso genoma ${ }^{2}$. A maioria é muito freqüente e cada uma delas pode estar presente em mais de $1 \%$ da população, estimando-se que dois indivíduos quaisquer difiram em um de cada 1.200 pares de bases de seu genoma. Essas variantes são consideradas polimorfismos (single nucleotide polymorphisms - SNP). Uma certa proporção, entretanto, pode ter conseqüências clínicas, contribuindo para a susceptibilidade a doenças que não são incomuns na população, como a diabetes e a hipertensão. Essas

FIGURA 1

International Human Genome Sequencing Consortium, "Finishing the Euchromatic Sequence of the Human Genome", in Nature, 431, 2004, pp. 931 -

R. Sachidanandam, D. Weissman, S.C. Schmidt, J.M. Kakol, L. D. Stein et al., "A Map of Human Genome Sequence Variation Containing 1.42 Million Single Nucleotide Polymorphisms", in Nature, 409 2001, pp. 928-33.
A
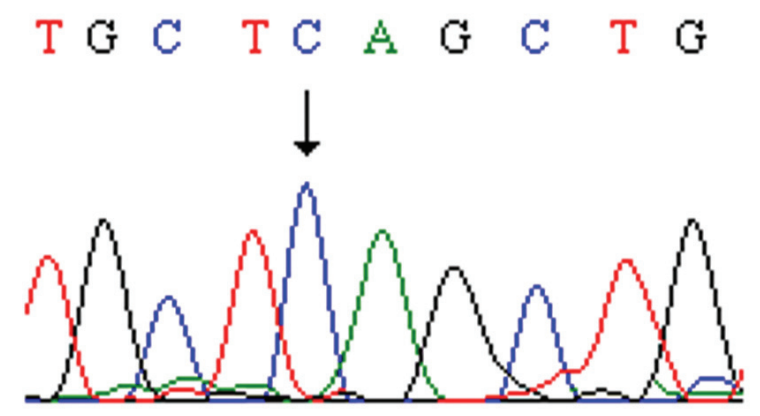

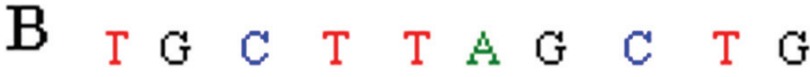

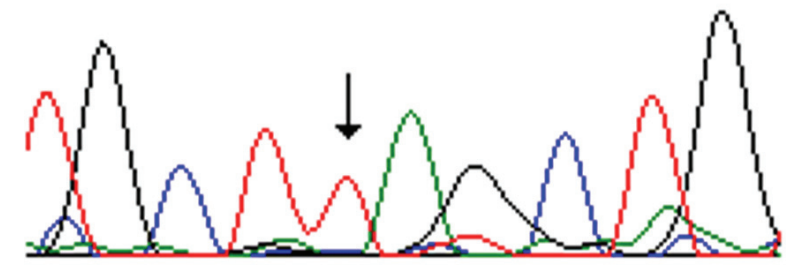

As seqüências de um segmento de certo gene diferem em um único par de bases: $C$ (citosina) no indivíduo $A$, e T (timina) no indivíduo B. Essa troca de $\mathrm{C}$ para $\mathrm{T}$ alterou o funcionamento do gene e causou deficiência mental em seu portador. O DNA dos indivíduos foi analisado em um seqüenciador automático. 
doenças têm mecanismos de determinação complexos em que se somam os efeitos das variantes genéticas com uma contribuição importante do ambiente. A contribuição das variações de bases únicas para essas doenças é um dos assuntos mais explorados atualmente nos estudos genéticos. Existem ainda alterações de bases que são muito raras na população e que têm um efeito drástico sobre o funcionamento dos genes, causando as doenças classificadas como de herança monogênica. Estão nesse grupo doenças genéticas como a surdez e as hemofilias. Essas alterações que causam efeitos clínicos são raras na população, pois as variantes do DNA estão sujeitas a seleção. Quanto mais graves os quadros clínicos associados a elas, mais prejudicada fica a reprodução de seus portadores e, portanto, a transmissão para as gerações seguintes.

Outras variações estruturais do genoma são mais extensas e abrangem segmentos do DNA que podem chegar a milhões de pares de base (megabases). Aquelas que incluem mais de cinco milhões de pares de base (5 $\mathrm{Mb}$ ) podem ser detectadas ao microscópio óptico quando se analisam os cromossomos (Figura 2). Essas alterações podem abranger muitos genes e estão presentes em três de cada mil recém-nascidos. Quando levam a perdas ou ganhos de segmentos cromossômicos, causam distúrbios gravesdodesenvolvimento e são causa importante de deficiência mental e defeitos congênitos. Essas alterações são encontradas em cerca de $50 \%$ dos abortos espontâneos, o que demonstra seu efeito letal sobre o desenvolvimento. Em cerca de metade dos casos, entretanto, a alteração cromossômica não leva a perdas ou ganhos, mas é um rearranjo em que os segmentos apenas mudam sua localização. Os portadores dessas alterações equilibradas em geral não têm doenças, mas sua reprodução fica prejudicada, pois podem formar gametas que contêm o rearranjo não equilibrado, ou seja, com ganhos ou perdas de segmentos cromossômicos. Porém, mesmo quando está equilibrada, a alteração cromossômica pode ter efeitos clínicos, por exemplo, causando esterilidade ou mesmo alguma doença genética, pois as quebras cromossômicas, que deram origem
FIGURA 2

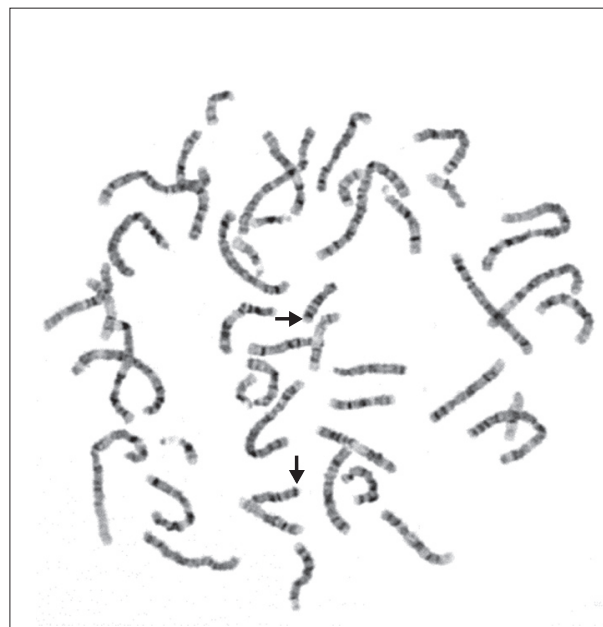

Cromossomos fotografados

ao microscópio após

coloração que diferencia

faixas claras e escuras em sua extensão e permite a identificação de cada par. As setas apontam para o par de cromossomos 18, um deles alterado devido à perda de um segmento. O portador dessa alteração apresenta malformações congênitas e retardo mental.

ao rearranjo, podem danificar genes. Assim, há uma forte seleção contra essas alterações cromossômicas, e a grande maioria delas não é transmitida de uma geração para outra.

Mais recentemente, estudos do genoma humano revelaram um grupo de variações estruturais que é intermediário entre as alterações de bases únicas e aquelas multimegabásicas detectadas ao microscópio com o uso de técnicas citológicas (Figura 3). Essas variações submicroscópicas do número de cópias de segmentos de DNA, abrangendo de alguns milhares de bases até os $5 \mathrm{Mb}$ da resolução do microscópio, já foram associadas a diversas alterações do 


\section{FIGURA 3}

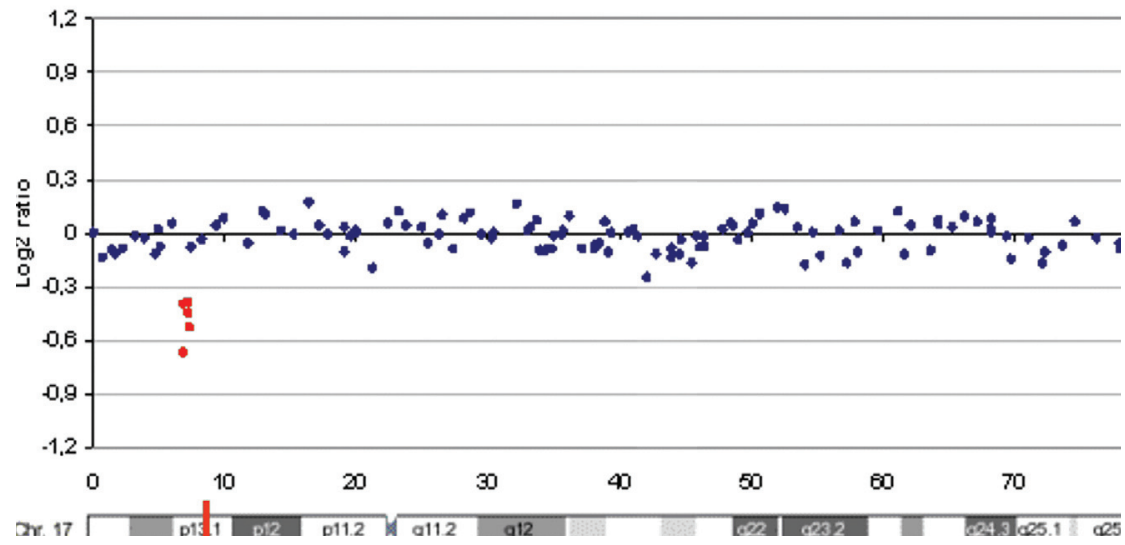

Para a detecção de perdas e ganhos de segmentos cromossômicos submicroscópicos, o genoma foi analisado por meio de hibridação genômica comparativa (comparative genomic hybridization - CGH). O DNA a ser testado foi marcado com um fluorocromo verde e o DNA de referência usado na comparação, marcado em vermelho. Os dois DNAs foram hibridados com segmentos do genoma fixados em uma lâmina. No caso, os segmentos clonados em BAC (Bacterial Artificial Chromosomes) tinham em média $100 \mathrm{~Kb}$ e estavam distribuídos por todo o genoma a espaços de $1 \mathrm{Mb}$. 0 gráfico, em escala logarítmica, mostra a relação do número de cópias de segmentos entre os cromossomos 17 dos genomas comparados.

desenvolvimento ${ }^{3}$. Por exemplo, investigações de pacientes com deficiência mental, cujo exame cromossômico convencional não mostrou alteração, revelaram microdeleções e microduplicações que podiam explicar o quadro clínico em 13-16\% dos casos $^{4}$. Genes que estão localizados nesses segmentos e que têm a dose de seus produtos alterada são candidatos a causadores desses quadros clínicos. Outros genes podem ter sido alterados pelas quebras que originaram os microrrearranjos. Entretanto, a relação entre a doença e essas alterações segmentares do genoma nem sempre é aparente, pois algumas delas podem ser herdadas de um genitor clinicamente normal. Essa 
discrepância pode ter algumas explicações na própria genética. Por exemplo, a perda de um segmento do cromossomo materno pode deixar a descoberto um gene alterado no cromossomo paterno correspondente, que o paciente herdou. A relação, porém, pode ser mais complexa, e a perda ou ganho de um segmento de DNA pode conferir susceptibilidade à doença e não ser determinante do quadro clínico por si só, como vimos acima para certas alterações de base única. Por outro lado, estudos populacionais mostraram que existem variações no número de cópias de segmentos de DNA que são relativamente freqüentes na população geral, constituindo polimorfismos (copy-number polymorphisms - CNP). Um desses estudos, por exemplo ${ }^{5}$, mostrou que, em média, cada indivíduo era portador de 104 variações, que abrangiam mais de 40.000 pares de bases e estavam presentes em pelo menos $3 \%$ da população. Cerca de $70 \%$ das variantes incluíam genes, alguns já relacionados aos sentidos (olfato, audição, visão e gosto) e à susceptibilidade a doenças complexas, como câncer, diabetes, esquizofrenia e doença de Alzheimer. Apesar de as variantes de pares de base únicos, os SNP, serem mais freqüentes no genoma do que as variações do número de cópias, estas afetam um maior número de pares de bases por genoma. Essas variantes de número de cópias de DNA, que são polimórficas na população, devem, portanto, constituir um componente genético importante da nossa variabilidade fenotípica.

Apenas começamos a entender o significado da variabilidade de nosso genoma.
5 K. K. Wong, R. J. De Leeuw N. S. Dosanih, L. R. Kimm, Z. Cheng, D. E. Horsman, C. MacAulay, R. T. Ng, C. J. Brown, E. E. Eichler, W. L. Lam, "A Comprehensive Analysis of Common Copy-number Variations in the Human Genome", in Am.J. Hum. Genet., 80, 2007, pp. 91-104. 